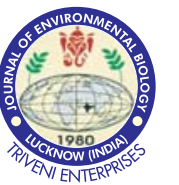

\title{
Molecular characterization of lytic phages specific to antibiotic resistant isolates of Pseudomonas fluorescens infecting Labeo rohita and Clarias batrachus of Sub Himalayan region
}

\section{Authors Info}

N. Dinkar', A. K. Sharma', A. S. Ninawe ${ }^{2}$ and Y. Prasad ${ }^{1 *}$

'Department of Animal Science, M.J.P. Rohilkhand University, Bareilly - 243006, India

'Department of Biotechnology, CGO Complex, Lodhi Road, New Delhi-110 003, India

*Corresponding Author Email : ypsinghh@gmail.com

Key words

Aquaculture

Genomic

Phage

Pseudomonas fluorescens

Publication Info

Paper received : 30.05 .2016

Revised received : 29.09 .2016

Re-revised received : 10.10 .2016

Accepted: 16.12.2016

\section{Abstract}

Aim : This investigation was aimed to develop antibacterial strategy to circumvent the problem of antibiotic resistant $P$. fluorescens infecting $L$. rohita and Indian walking catfish, $C$. batrachus in Himalayan and Sub Himalayan regions.

Methodology : Four lytic phages (PFPD, PFPK, PFPN and PFPC) were isolated against ten isolates of pathogenic $P$. fluorescens following overlay method using water and bottom sediments of Himalayan and Sub Himalayan regions. One step growth experiment was carried out to know the eclipse, latent periods and burst size of phages. Phage genomic DNA was extracted following chloroform: phenol: isoamyl method and digested using restriction enzymes (EcoRI and Hind III) (Bangalore genei, Bangalore) and isolation of phage protein was made as per Laemmli (1970) with slight modification.

Results : Phages were identified as a member of family Siphoviridae (isometric head of $236.42 \mathrm{~nm}$ and non-contractile long tail of $521.22 \mathrm{~nm}$ ) with having ds DNA of 20-21 kbp and structural viral proteins of 22 $102 \mathrm{kDa}$. Phages exhibited minimum eclipse period (10 - $15 \mathrm{~min})$, latent period (20 $\mathrm{min}$ ) and highest burst size of 130. These phages conferred clear lytic plaques in the lawn of 8 of $10(80 \%)$ host bacterium at $0.01 \mathrm{MOI}$, tolerated wide range of temperature $\left(25\right.$ to $\left.35^{\circ} \mathrm{C}\right), \mathrm{pH}$ (6.5 to 8.0), yielded highest titer ( $10^{8} \mathrm{pfu}$ ) at $30 \pm 5^{\circ} \mathrm{C}$ and exhibited highest (99\%) in vitro lytic activities. The host bacterium did not develop resistance to all the phages studied during the entire period of the study.

Interpretation : The profound in vitro lytic attributes of PFPD and PFPK phages and their tolerance to temperature and $\mathrm{pH}$ at par with aquaculture activities reveals that they may be a suitable option to alleviate transmission of even systematic $P$. fluorescens infection in hatchery and culture system. This information will provide more insight into the potential use of phage to mitigate incidences of Bacterial Haemorrhagic Septicaemia in aquaculture.

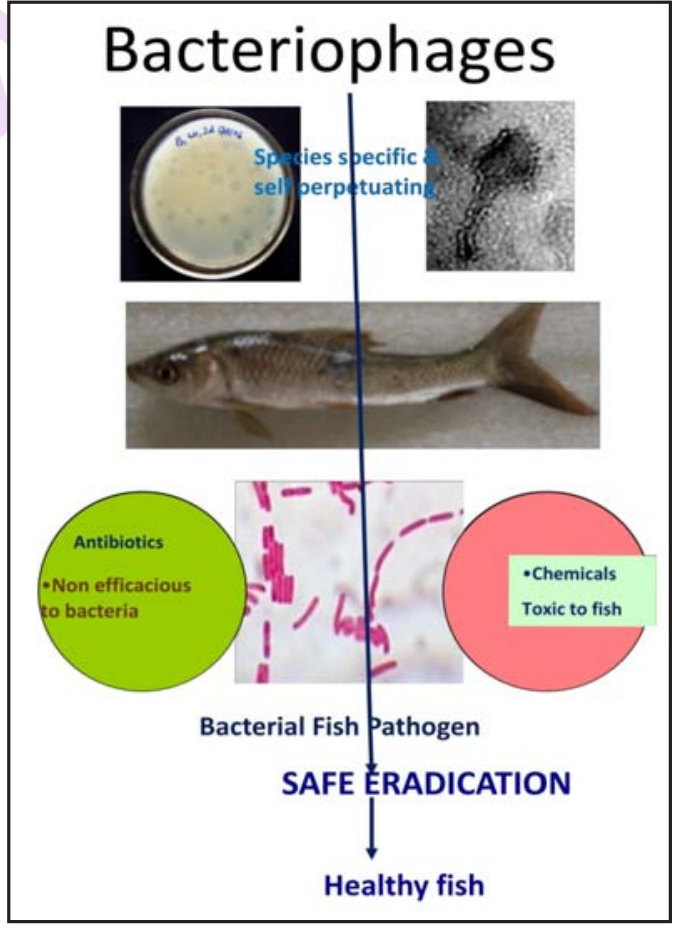




\section{Introduction}

Pseudomonas fluorescens is a Gram-negative rod shaped bacterial fish pathogen that has been found to be associated with Bacterial Haemorrhagic Septicaemia (BHS) in cultivable Indian Major Carps - IMC (L. rohita, Catla catla, Cirrhinus mrigala), common carps, Cyprinus carpio communis (Prasad and Qureshi, 1994), ulcered C. batrachus (Prasad and Qureshi, 1995) and other aquatic animals (Parvez and Mudarris, 2014) and causes a great economic loss to aquaculture. Its persistent occurrence with several ulcerative diseases of carp $(L$. rohita and C. carpio), catfish, C. batrachus (Prasad et al., 2011) and Epizootic Ulcerative Syndrome (EUS) infected fish (Qureshi et al., 2000; Darak and Barde, 2015) that has virtually devastated the Indian fisheries industries during 1990 has attracted the attention for its remedial measures.

The common control methods of $P$. fluorescens infection are based on the application of quick lime in case of seasonal ponds and $\mathrm{KMnO}_{4}$ and antibiotics in hatchery and culture ponds (Prasad et al., 2010). Moreover, various isolates of $P$. fluorescens have been found to be resistant (in vitro) to commonly used antibiotics (Prasad, 2008; Bekta and Yıldırım, 2013). Concerns of antibiotic resistance have also brought attention due to the large amount of antibiotics used in animal production, also in aquaculture (Hollis and Ahmed, 2013). Exposure of environmental microbes, including bacterial pathogens to antibiotics used in aquaculture through fish feed (Cabello et al., 2013) has enabled them to develop resistance (Di Cesare et al., 2013). Moreover, attempts have been made to search out effective control methods for mitigation of $P$. fluorescens infection in aquaculture using phages as remedial measures (Prasad et al., 2010).

Since the discovery of phages, they have been used as remedial measures to combat with the antimicrobial resistance. Phages are viruses that subsist on bacteria and generally lead a lytic life in which survival of the host bacterium becomes extremely difficult. This nature of phage has attracted its use as therapeutic agent. Moreover, a good number of phages has been characterized against a number of freshwater bacterial fish pathogens viz. P. aeruginosa (Kumari et al., 2009; Khairnar et al., 2013), Flavobacterium columnare (Prasad et al., 2010, 2011; Laanto et al., 2014, 2015), F. psychrophilum (Christiansen et al., 2016; Muziasari et al., 2016) and P. fluorescens, the causative agent of BHS in fish (Prasad et al., 2010; Radhakrishnan and Subramanian, 2012).

The phages identified so far are made of hexagonal head consisting DNA within a protein capsid and a tail comprising of lipid or protein (Taddei and De Paepe, 2006). Most of the phages identified generally contain double-stranded DNA as their genetic material (Radhakrishnan and Subramanian, 2012). More than 95 $\%$ of known phages belong to the order Caudovirales (Maniloff and Ackermann, 1998) with main families viz. Myoviridae (long double-layered contractile tail), Siphoviridae (long non flexible tail) and Podoviridae (short stubby tail) and are distinct based on morphological characteristic, in particular, tail-shape (Deveau et al., 2006). Phages are species specific, they attack their targeted bacteria, inject their DNA into the host which replicates there in and leads to death of bacterial cell without disturbing the non targeted bacteria. Hence, phages are relatively safe bactericidal candidates as they have no harmful effect against animal or plant cells (Kutter and Sulakvelidze, 2004) and do not affect other beneficial microorganisms. In addition, they can be easily isolated from the native host bacterial environment.

In view of the above, the present study was carried out to investigate an appropriate strategy to circumvent the problem of antibiotic resistant $P$. fluorescens, which would provide more insight into the potential use of phage to mitigate incidences of Bacterial Haemorrhagic Septicaemia in aquaculture.

\section{Materials and Methods}

Bacterial isolates : A total of ten P. fluorescens (PF1 - PF10) isolates, used in the present study, were isolated from different water bodies of Himalayan (Nainital Lake) and Sub - Himalayan, Ganga river at Kanpur and fish ponds (Delapeer Talab, Choudhary fish culture Talab) of Rohilkhand region using Brain Heart infusion broth / Pseudomonas isolation agar (BHI / PIA HiMedia, Mumbai). All P. fluorescens isolates used in the study were identified according to Austin and Austin (2012) as Pseudomonas on the basis of scoring selective biochemical tests (catalase, gelatin degradation, nitrate, oxidase, fluoricin pigmentation, MR -VP reaction, $\mathrm{H}_{2} \mathrm{~S}$ production) and compared with ATCC 13525 using phage typing (Chinthala and Gundala, 2013), which were distinctive for $P$. fluorescens. To determine the optimal temperature and $\mathrm{pH}$ requirements, $P$. fluorescens $(\mathrm{PF})$ isolates were subjected to different temperature $\left(5-40^{\circ} \mathrm{C}\right)$ and $\mathrm{pH}(5.0$ 8.5) value adjusting by $1 \mathrm{~N} \mathrm{NaOH} / 1 \mathrm{~N} \mathrm{HCl}$ and incubation period (24-96hr) following Buchanan and Gibbons (1974).

Phage isolation and purification : Four lytic phages were isolated against ten isolates of $P$. fluorescens following Sambrook and Russell (2001), with slight modification using water and bottom sediments of Nainital Lake Uttrakhand, Ganga river at Kanpur and Fish ponds (Delapeer Talab, Choudhary fish culture Talab) of Rohilkhand region.

Propagation of phage : Amplification of polyvalent phages (PFPD, PFPK, PFPN and PFPC) was accomplished through liquid culture technique and streak plate method. The Pseudomonas Isolation Agar (PIA) medium containing 1\% agar was poured in Petri-dishes and overlaid with $5 \mathrm{ml}$ soft medium

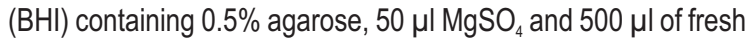
culture of $P$. fluorescens. After solidification inoculating loop was touched on the surface of plaques and streaked on overlaid plate, incubated at $30 \pm 5^{\circ} \mathrm{C}$ in BOD incubator (REMI) for $16-18 \mathrm{hr}$ and examined for the appearance of inhibitory zone at streak line in the bacterial lawn. 
Plaques appeared in bacterial lawn were scrubbed using sterilized inoculating loop, filled with SM medium and kept for $4 \mathrm{hr}$ in refrigerator. Later, the suspension was eluted, centrifuged (8000 rpm), filtered $(0.22 \mu \mathrm{m})$ and stored in glass tubes at $4^{\circ} \mathrm{C}$ until use.

Determination of multiplicity of infection (MOI) pfu: cfu: To determine accuracy of bacteria (cfu) verses phages (pfu) for getting exact dose, an experiment was conducted in vitro using broth culture challenging PF10 bacterium with PFPD phage (pfu : cfu) @ $1: 10^{1}, 1: 10^{2}, 1: 10^{3}$ and $1: 10^{4}$ following the method of Prasad et al. (2011) and dilution in which maximum reduction recorded in mean cfu value was determined as multiplicity of infection (MOI).

One step growth experiment : In order to know the eclipse, latent periods and burst size one step growth experiment of phages was conducted. For this, $100 \mathrm{ml}$ suspension of phage (PFPD) and bacterium (PF4) was prepared at an MOI of 0.01 , vortexed and incubated at $30 \pm 2^{\circ} \mathrm{C}$. Sample were collected ( $1 \mathrm{ml}$ ) at $0,10,20,30,40,50$ and 60 min to check the pfu. Fifty percent of the sample was centrifuged at $10,000 \mathrm{rpm}$, filtered $(0.22 \mu \mathrm{m})$ and rest was used as non-filter sample. $100 \mu$ of filtered and nonfiltered samples were overlaid separately (in triplicate) on hard PIA medium to enumerate pfu.

Stability test : To know phage stability at various temperatures, phage aliquots $\left(10^{8} \mathrm{PFU} \mathrm{ml}{ }^{-1}\right)$ in SM buffer were incubated at 5,10 , $15,20,25,30,35$ and $40^{\circ} \mathrm{C}$ for 24 min. Similarly for pH stability, phage aliquots were added to SM buffer adjusted with $1 \mathrm{~N} \mathrm{HCl}$ or $1 \mathrm{~N} \mathrm{NaOH}$ to a $\mathrm{pH}$ range of 4.5 to 11.0 and incubated at room temperature for $1 \mathrm{hr}$ followed by phage titer using a plaque assay.

Morphology of phage : A drop of suspension containing high concentration of phage $\left(10^{6.8} \mathrm{pfu} \mathrm{ml} \mathrm{m}^{-1}\right)$ fixed in $2.5 \%$ of $\beta$ glutaraldehyde for $1 \mathrm{hr}$ and washed with $0.1 \mathrm{M}$ Disodium phosphate buffer ( $\mathrm{pH}-7.2)$ was put on the carbon-coated grid, left for 2 min and excess aliquot was removed with the help of a filter paper. Thin film developed on carbon coated grid was negatively stained with $2 \%$ aqueous Urenyl acetate $(\mathrm{pH} 4.0)$, examined using transmission electron microscope (TEM; JEOL, Japan) and images were scanned at $80 \mathrm{kv}$ at All India Institute of Medical Science (AlIMS), Delhi. The phages were classified according to the guidelines of the International Committee on Taxonomy of Viruses (ICTV) (Fauquet et al., 2005).
Extraction of phage genomic DNA and restriction enzyme digestion : Phage genomic DNA was extracted using chloroform: phenol: isoamyl following Sillankorva et al. (2008) with slight modification. Briefly, $500 \mu \mathrm{l}$ phage sample $\left(10^{8} \mathrm{pfu} \mathrm{ml}^{-1}\right)$ was added with $10 \mu \mathrm{l}$ of $0.5 \%$ SDS and proteinase K (Bangalore genei, Bangalore) at a final concentration of (0.05) mg ml${ }^{-1}$ and incubated at $65^{\circ} \mathrm{C}$ for $15-30 \mathrm{~min}$ in a water bath. Thereafter, equal volume of Phenol: chloroform: Isoamyl was added to remove proteinaceous material and extracted (3X). After Phenol: chloroform: Isoamyl treatment nucleic acid was precipitated with $70 \%$ chilled ethanol and suspended with $20 \mu$ nuclease free water (Millipore) and electrophoresed for confirmation of phage DNA. The phage DNA was digested with restriction enzymes (EcoRI and Hind III), following standard restriction digestion assay as per manufacturer's instructions (Bangalore genei, Bangalore) and electrophoresed using 0.7 percent agarose gel.

Phage protein isolation : The procedure developed by Laemmli (1970) was followed with slight modification for the isolation of phage protein. Briefly, to isolate phage proteins 15\% sodium dodecyl sulphate polyacrylamide gel electrophoresis (SDSPAGE) was performed using filtered $(0.22 \mu \mathrm{m})$ PFPD, PFPN and PFPK phages mixed with (20:20) sample buffer $(0.0625 \mathrm{M}$ Tris $\mathrm{HCL}, \mathrm{pH} 6.8,1 \%$ SDS, $15 \%$ glycerol and $1 \%$ beta mercaptoethanol bromophenol blue). Before running gel mixture of phage, sample buffer was heated for $5 \mathrm{~min}$ at $90-95^{\circ} \mathrm{C}$ in a water bath. Samples were loaded in gel along with protein marker (NEX- GEN Pink ADD pre stained protein Ladder). The protein bands developed were visualized after staining the gel with silver stain.

\section{Results and Discussion}

Ten of twenty isolates of Pseudomonas spp. isolated from diseased $L$. rohita and $C$. batrachus conferred positive response to oxidative, oxidase, catalase, gelatin degradation, nitrate, lysine, citrate utilization and fluoricin pigmentation tests and negative to $\mathrm{H}_{2} \mathrm{~S}$ production, indole and MR-VP reactions at par with P. fluorescens (ATCC 13525) were numbered as PF1 - PF10. They formed well developed colonies at optimal temperature of $30 \pm 5^{\circ} \mathrm{C}$ and at $\mathrm{pH} 7.2 \pm 0.2$, but failed to proliferate at $45^{\circ} \mathrm{C}$ and pH below 6.0 and above pH 9.0. Four lytic phages viz. PFPD, PFPK, PFPN and PFPC isolated using water samples of Himalayan (Nainital lake) and Sub- Himalayan region - Ganga river at Kanpur and fish ponds (Choudhary Talab, Delapeer Talab)

Table 1: Lytic phages isolated from different water bodies of Himalayan and Sub- Himalayan regions

\begin{tabular}{lllllll}
\hline SI. No. & Name of phage & Sampling site & Place & Type of plaque & Size of plaque & Test org. PF \\
\hline 1 & PFPD & Delapeer Talab & Bareilly & Discriminate & $6.5 \mathrm{~mm}$ & PF4/PF10 \\
2 & PFPK & Kanpur river & Kanpur & Discriminate & $5.2 \mathrm{~mm}$ & PF4/PF10 \\
3 & PFPN & Naini lake & Nainital & Discriminate & $7.4 \mathrm{~mm}$ & PF4/PF10 \\
4 & PFPC & Chaudhari Talab & Bareilly & Indiscriminate & $<3 \mathrm{~mm}$ & PF4/PF10 \\
\hline
\end{tabular}


Table 2 : Eclipse and latent periods of filtered and non filtered phages of $P$. fluorescens isolated from diseased fish

\begin{tabular}{lllll}
\hline Phages & \multicolumn{2}{c}{ Filter sample } & \multicolumn{2}{c}{ Non- filter sample } \\
\cline { 2 - 5 } & Eclipse period(min) & Latent period(min) & Eclipse period(min) & Latent period(min) \\
\hline PFPD & $3.13 \pm 0.15$ & $3.43 \pm 0.12$ & $3.14 \pm 0.07$ & $3.04 \pm 0.07$ \\
PFPN & $2.99 \pm 0.01$ & $3.28 \pm 0.02$ & $3.09 \pm 0.08$ & $3.11 \pm 0.05$ \\
PFPK & $3.02 \pm 0.03$ & $3.24 \pm 0.01$ & $3.14 \pm 0.04$ & $3.10 \pm 0.04$ \\
PFPC & $2.19 \pm 0.10$ & $2.71 \pm 0.04$ & $2.80 \pm 0.06$ & $2.73 \pm 0.01$ \\
\hline
\end{tabular}

Table 3: Host range sensitivity of four lytic bacteriophages against ten isolates of $P$. fluroscense

\begin{tabular}{lllllllllllll}
\hline I No. & PF Phage & PF1 & PF2 & PF3 & PF4 & PF5 & PF6 & PF7 & PF8 & PF9 & PF 10 & Host Range \\
\hline 1 & PFPD & + & - & + & + & + & + & + & + & - & + & 8 \\
2 & PFPK & - & - & + & + & - & + & + & - & - & + & 5 \\
3 & PFPN & + & - & - & + & + & - & - & + & - & + & 5 \\
4 & PFPC & - & - & + & + & + & + & - & - & - & + & 5 \\
\hline
\end{tabular}

of Rohilkhand region against $10 P$. fluorescens isolates obtained from diseased fish. The phages developed in the form of indiscriminate micro plaques (Fig. 1A) of $<3 \mathrm{~mm}$ in the samples of Choudhary Talab, Bareilly (fed with sewage water) and discriminate macro plaques (Fig. 1B) of 5.2 to $7.4 \mathrm{~mm}$ in the samples of fish ponds and riverine water within $18-24 \mathrm{hr}$. Phages isolated from Delapeer Talab, Ganga river at Kanpur, Nainital lake and Choudhary Talab were designated as PFPD, PFPK, PFPN and PFPC (Table 1), respectively. The population of indiscriminable and discriminable plaques was enumerated to $10^{8}$ pfu $\mathrm{ml}^{-1}$ in sewage water and bottom sediment of fish ponds. It explicates the ubiquitous distribution of $P$. fluorescens phages in fish pond and reverine system. The occurrence of phages against F. psychrophilum which causes rainbow trout fry syndrome and cold water disease (Stenholm et al.,2008;) (Castillo et al. 2014) reported from water and bottom sediments. The host range sensitiveness of four phages (PFPD, PFPK, PFPN and PFPC) determined against ten strains (PF1- PF10) of $P$. fluorescens revealed that the phages of present isolates were effective against all the isolates of $P$. fluorescens. But PFPD and PFPN phages were highly effective against PF4 and PF10 bacterial isolates. Result of phages PFPD, PFPN, PFPK and PFPC amplification accomplished through streak plate revealed the highest inhibitory zones (Fig. $2 \mathrm{~A}$ and $\mathrm{B}$ ) which were eluted in

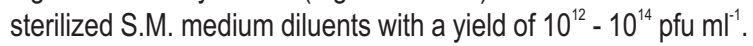
Diverge plaque sizes of $P$. fluorescens phages were also recorded (Prasad et al., 2011). The virulent phages make the survival of host bacterium extremely difficult, and hence is considered as an important therapeutic agent to mitigate the antibiotic resistance of bacterial pathogens (Prasad et al., 2010; 2011; Castillo et al., 2014). The capability of phage to increase in number during the infectious process makes phages excellent potential diagnostic and therapeutic agents to combat bacterial pathogens. It advocates that they have a high range of infectivity and bear profound virulent attributes. It strongly supports that lytic phages (PFPD and PFPK) would be a potential candidate to mitigate the population of $P$. fluorescens below threshold level in aquaculture. Recent findings made in $P$. fluorescens (Radhakrishnan and Subramanian, 2012), F. columnare (Prasad et al., 2011; Laanto et al., 2014, 2015), A. salmonicida (Imbeault et al., 2006), F. psychrophilum (Stenholm et al., 2008; Castillo et al., 2014; Christiansen et al., 2016; Muziasari et al., 2016) and $P$. aeruginosa (Kumari et al., 2009; Khairnar et al., 2013) phages are in conformity with the present findings. Electron microscopy of two P. fluorescens phages (PFPD and PFPK) revealed the presence of a large isometric hexagonal head of $236.42 \mathrm{~nm}$ with a long non-contractile tail of $521.22 \mathrm{~nm}$ (Fig. 3) and were similar in their morphologies. The head and tail dimensions of these phages closely resembled to Siphoviridae family (Ackerman, 2005) and their persistent infection confirmed that they were DNA virus, however, in the present study molecular evaluation also explicated that they were DNA virus.

Response of four phages (PFPD, PFPK, PFPN and PFPC) to diverse temperature $\left(5^{\circ}-40^{\circ} \mathrm{C}\right)$ and $\mathrm{pH}(4.5-11.0)$ explicated that they could proliferate very well at $25^{\circ}-35^{\circ} \mathrm{C}$, but failed to produce plaques below $25^{\circ} \mathrm{C}$ and above $40^{\circ} \mathrm{C}$. The mean pfu values were brought down to the minimum at $40^{\circ} \mathrm{C}$ and were completely inactivated at $45^{\circ} \mathrm{C}$. A decrease in viability in terms of pfu count varied depending on the specific phage. All phages were found to be stable at $\mathrm{pH} 6.5$ to 9.0 but were inactivated at $\mathrm{pH}$ 10. Highest lytic activity of phages of $P$. fluorescens (Prasad et al., 2010), S. aureus (Gupta and Prasad, 2011) and F. columnare (Prasad et al., 2011; Laanto et al., 2014, 2015) was reported at 10 to $45,37.5$ and 5 to $40^{\circ} \mathrm{C}$ and $\mathrm{pH} 6.5$ to 8.0 and $<6.5$ to $>10.5$, respectively, on which host bacterium prefers to proliferate. 

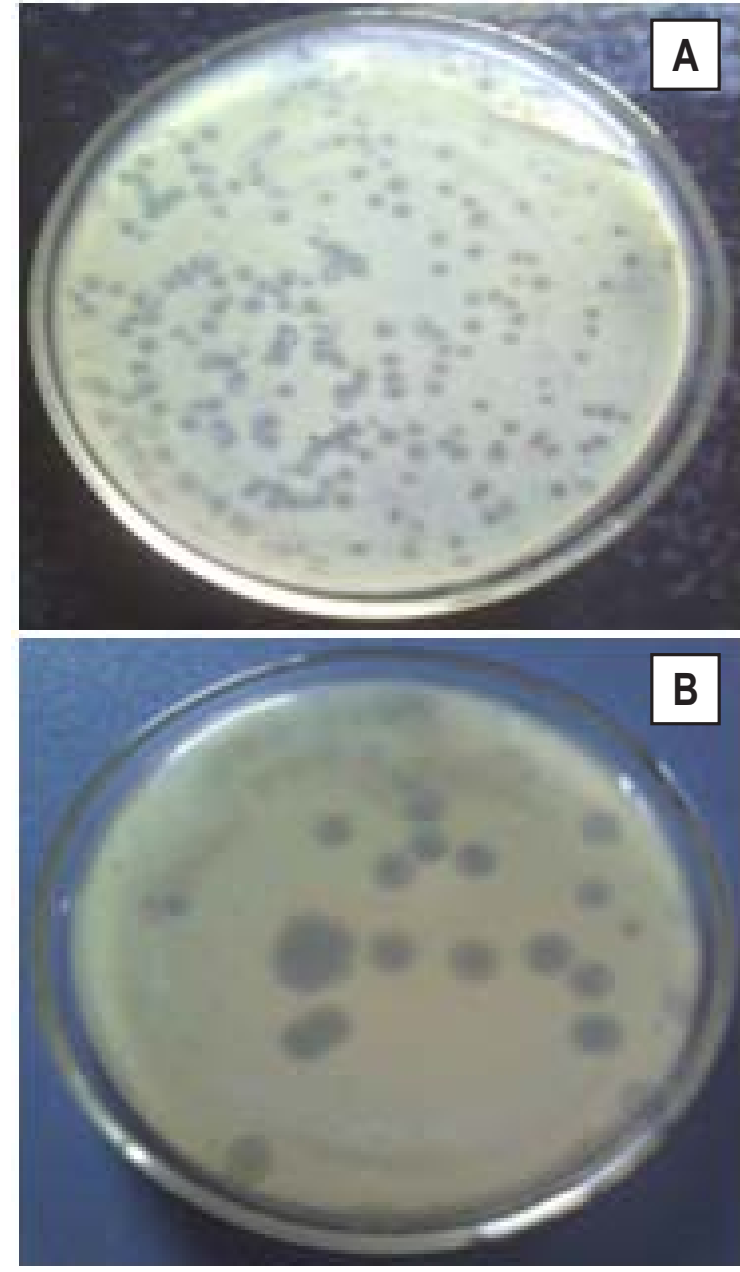

Fig.1 : Well developed Micro <3mm (A) and Macro (B) of $5-7 \mathrm{~mm}$ of PFPD phage plaques marked with bald spots in the lawns of $P$. fluorescens (PF10) developed on PIAmedium

There were variations in the latency of filtered phages tested as the initial mean $\log 10$ pfu value of PFPD, PFPK, PFPN and PFPC was noted to $3.13 \pm 0.15,2.99 \pm 0.01,3.02 \pm 0.03$ and $2.19 \pm 0.10$ at $0 \mathrm{~min}$ (Table 2). There was nonoccurrence of plaques up to 10 to $15 \mathrm{~min}$ and recurrence of phage plaques with slight increase in mean $\log 10$ value at $20 \mathrm{~min}$. This value augmented by more than 1 to 2 logs at 40, 50 and $60 \mathrm{~min}$ (Fig. 4). On the contrary, in non - filtered phage the initial mean log10 pfu count of PFPD, PFPK, PFPN and PFPC was noted to $3.14 \pm 0.07$, $3.09 \pm 0.08,3.14 \pm 0.04,2.80 \pm 0.06$ at 0 min which exhibited nonoccurrence of plaques up to $20 \mathrm{~min}$. There was recurrence of plaques after $20 \mathrm{~min}$ with a concomitant elicitation of 1 to $2.5 \mathrm{logs}$ at $30,40,50$ and $60 \mathrm{~min}$. It revealed that the eclipse period of PFPD phage would be $10-15$ min because there was loss of
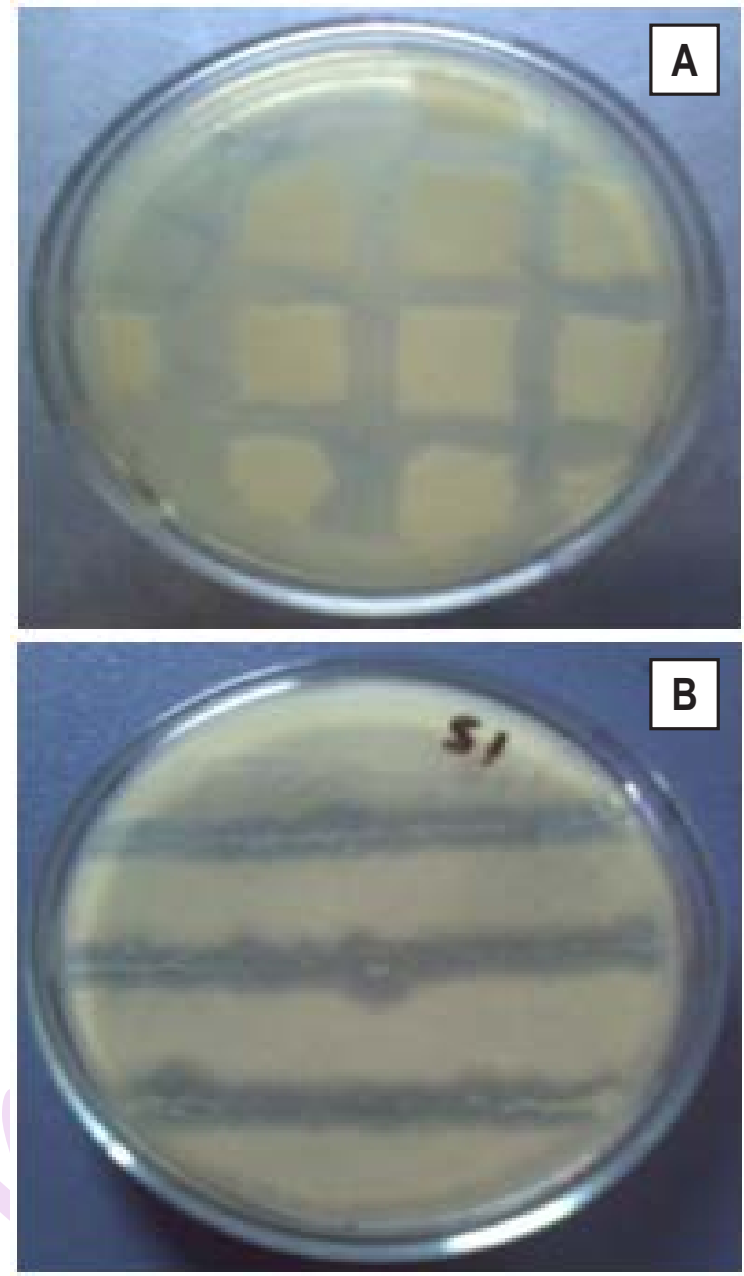

Fig. 2 : Horizontal and vertical eroded zones (A) and horizontal eroded zones (B) as an indication of inhibitory lines of PFPD phage streaked over the surface of $P$. fluorescens (PF10) lawn grown on PIA medium

plaques during this period. The latent period was 20 min because there was reappearance of plaques more than its initial value. The burst size of PFPD phage was enumerated to 130. The result of one step experiment suggested that PFPD phage had minimum eclipse period and maximum burst size at temperature suitable for host bacterium $\left(25^{\circ}-35^{\circ} \mathrm{C}\right)$ and aquaculture. Variation in adsorption rate, eclipse period (10-20 $\mathrm{min}$ ) and burst size per bacterial (180 -370) cell has also been recorded in case of $P$. aeruginosa (Kumari et al., 2009) and F. columnare phages (Prasad et al., 2010).

Lytic activity of phages is one of the most important factors for their application as therapeutic candidate to combat with the spread of antibiotic resistant bacterial pathogens. Result 


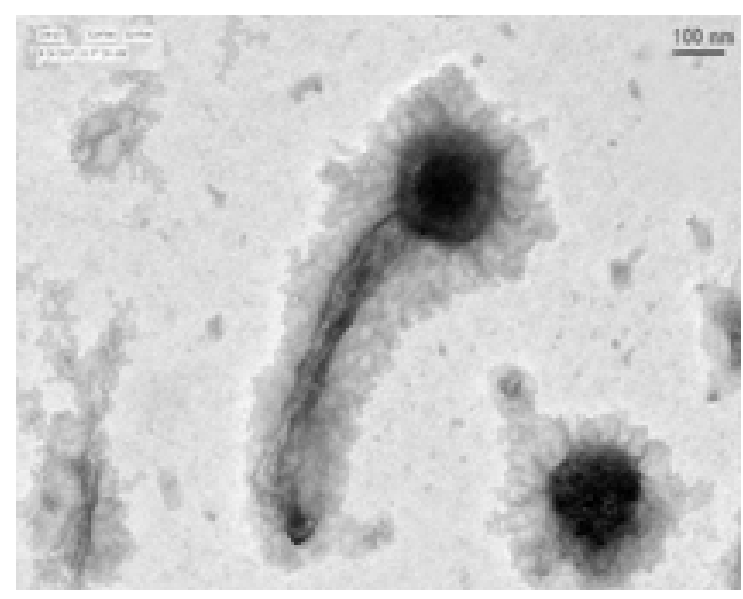

Fig. 3 : PFPD phage specific to $P$. fluorescens (PF10) marked with large isometric hexagonal head $(236.42 \mathrm{~nm})$ with a long non-contractile tail $(521.24 \mathrm{~nm})$ a member of Siphoviridae (TEM)

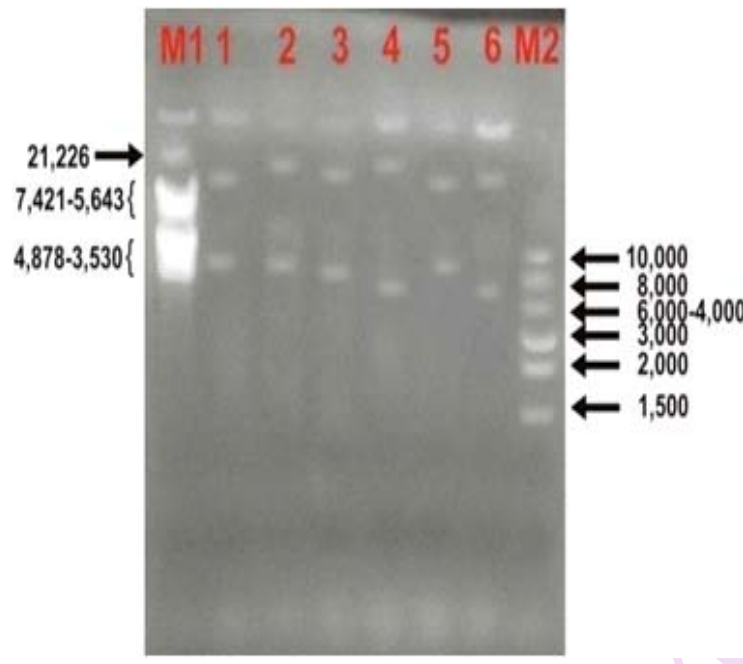

Fig. 5 : Restriction enzyme digestion of DNA isolated from different phage sample (PFPD, PFPN, PFPK).Lane $1 \mathrm{M1}, \lambda$ EcoRl; Lane 2, PFPD digested with $\lambda \mathrm{EcoRI}$; Lane 3, PFPN digested with $\wedge$ EcoRl; Lane 4, PFPK digested with $\lambda$ EcoRl; Lane 5, PFPD digested with Hind III; Lane 6, PFPN digested with Hind III; Lane 7, PFPK digested with Hind III; Lane $8, \mathrm{M} 21 \mathrm{~Kb}$

of sensitiveness of different isolates of $P$. fluorescens (PF1 PF10) to four selected phages ( PFPD, PFPK, PFPN and PFPC) revealed that PF 4 and PF10 P. fluorescens isolates were lysed by all the four phages used. The PFPD phage lysed 8 of $10(80 \%)$ of host bacterium, hence it was selected for further experimentation while rest of the phages (PFPK, PFPN and PFPC) lysed only $50 \%$ of $P$. fluorescens isolates (Table 3 ). The results of comparative

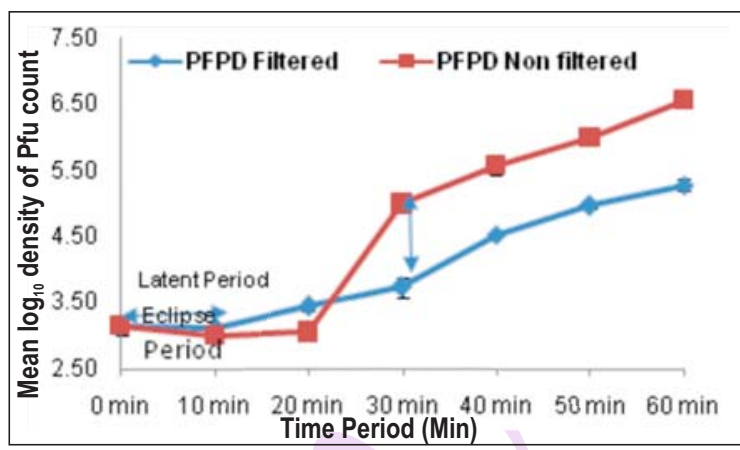

Fig. 4 : Mean $\log _{10}$ pfu of PFPD phage grown in broth culture of PF10 bacterium $\mathrm{PI}$ with filtered and non-filtered phages

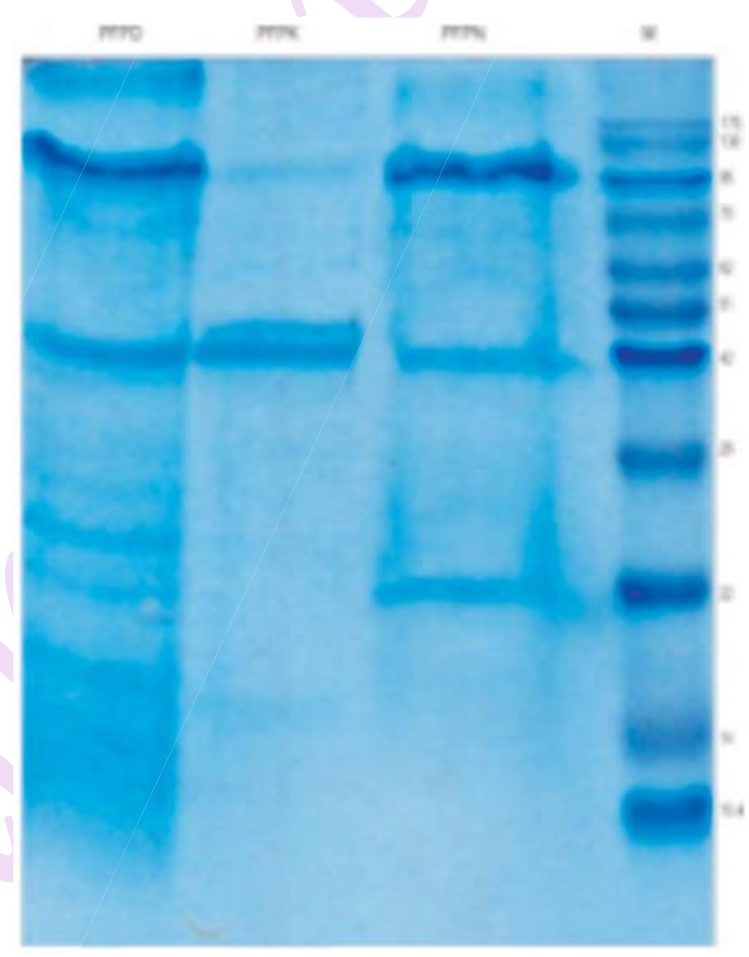

Fig. 6 : Three major structural protein bands of approximately 102,45 and $42 \mathrm{kDa}$ of PFPD, PFPK and PFPN phages of $P$. fluorescents respectively belonging to Siphoviridae assessed through SDS-PAGE (Lane M, protein molecular weight marker (kilobases), lane A, PFPD, lane B, PFPK, lane C, PFPN)

Iytic activity of selected phages checked in different water samples (Brain Heart Infusion broth -BHI, distilled water and pond water) explicated a decrease in mean $\log _{10}$ cfu value of $\mathrm{BHI}$ broth after $6 \mathrm{hr}$ of phage inoculation. This value further declined to minimum to its original concentration at $48 \mathrm{hr}$ period. Similar trend was also noticed in distilled water except fishpond water where it was delayed. 
The genomic DNA of three purified phages (PFPD, PFPK and PFPN) extracted using Phenol: Chloroform: Isoamyl and digested with EcoRI and Hind III restriction enzymes and subjected to restriction enzyme digestion patterns explicated that all these phages had genome of 20-21 kbp size (Fig. 5) with slight variation in their size pattern. The $P$. fluorescens phages were found to exhibit different banding pattern with Hind III and EcoRI restriction enzymes which confirmed that all Pseudomonas phages carry ds DNA with slight genomic diversity. However, $P$. fluorescens phages of distinct genomic diversity of 26-82 kbp have been isolated from sewage water (Radhakrishnan and Subramanian, 2012). Variations in DNA sizes have been recorded: $37 \mathrm{~kb}$ of $P$. aeruginosa phage MP22 (Goszczynska et al., 2000), $58 \mathrm{~kb}$ of D3 phage (Kwan et al., 2006) and $24 \mathrm{~kb}$ of phages of $P$. aeruginosa belonging to family Podoviridae (Kumari etal., 2009).

Protein analysis of three $P$. fluorescens phages (PFPD, PFPK and PFPN) belonging to Siphoviridae family showed three major structural protein bands of approximately 102, 45 and $42 \mathrm{kDa}$ and 1 minor structural protein band of molecular weight approximately $22 \mathrm{kDa}$ (Fig. 6). There were variations in their structural protein distribution. The proteins of molecular weight of $102 \mathrm{kDa}$ and 22kDa were present in two phages (PFPD and PFPN), while protein of molecular weight of $42 \mathrm{kDa}$ was present in all three phages. It suggested that there were variations in molecular weight of major proteins which varied among phage lysate specific to same bacterial strain. It has conformity to the proteins of phages specific to $P$. aeruginosa (Kumari et al., 2009) and $P$. fluorescens isolated from sewage water (Radhakrishnan and Subramanian, 2012).

In conclusion, the result of the present study provides evidence of profound lytic impact of $P$. fluorescens phages (PFPD, PFPN, PFPK and PFPC) and represents their interesting therapeutic importance to combat with the problems caused by this pathogen in fish. It also signifies that PFPD and PFPK phages may be highly suitable to alleviate transmission of even systematic PF infection in hatcheries and culture systems.

\section{Acknowledgments}

The authors are thankful to DBT, Government of India, New Delhi for financial assistance. Thanks are also due to Prof. T.A. Qureshi for his constructive criticism and valuable suggestions rendered during the preparation of this manuscript.

\section{References}

Ackermann, H. W.: Bacteriophage classification. In : Bacteriophages: Biology and applications. (Ed. E. Kutter and A. Sulakvelidze), CRC Pub. Boca Raton, FL, pp. 67-90 (2005).

Austin, B. and D. A. Austin: Bacterial Fish Pathogens: Disease of Farmed and Wild Fish $5^{\text {th }}$ Edn. Springer, pp.654 (2012).

Bekta, S. and A. Yıldırım: Antimicrobial susceptibility of fish pathogen bacteria; Pseudomonas fluorescens isolated from Çoruh river Ospir/Erzurum/Turkey) 2nd Inter. Conf. on Adv. in Biological and Pharm. Sci., 17-18 (2013).

Buchanan, R. E. and N. E. Gibbons: Bergey's Manual of Determinative Bacteriology 8th Edn., Williams \& Wilkins Co., Baltimore p. 1246 $\mathrm{pp}$ (1974).

Cabello, F.C., H. P. Godfrey, A. Tomova, L. Ivanova, H. Dölz, A. Millanao and $\mathrm{A}$. H. Buschmann: Antimicrobial use in aquaculture reexamined: its relevance to antimicrobial resistance and to animal and human health. Environ. Microbiol. , 15, 1917-1942 (2013).

Castillo, D., R. H. Christionson, R. Espejo and M. Middelbae: Diversity and geographical distribution of Flavobacterium psychrophilum isolates and their phages: patterns of susceptibility to phage infection and phage host range. Microbial. Ecol., 67, 748-757 (2014).

Chinthala, P. and P. B. Gundala: Morphological, Biochemical and functional characterization of $P$. fluorescens strains isolated from forest litter Seshachalum Hill range. Int. J. Res. Pure Appl. Microbiol., 3, 1-3 (2013).

Christiansen, R.M., L. Madsen, I. Dalsgaard, D. Castillo, P.G. Kalatzis and M. Middelboe: Effect of bacterophage on the growth of Flavobacterium psychrophilum and development of phage resistant strains. Microbiol. Ecol., 71, 845-859 (2016).

Darak, O. and R. D. Barde: Pseudomonas fluorescens associated with bacterial disease in Catla catla in Marathwada Region of Maharashtra. Int. J. Adv. Biotechnol. Res., 6, 189-195(2015).

Deveau, H., S. J. Labrie, M. C. Chopin and S. Moineau: Biodiversity and classification of lactococcal phages. Appl. Environ. Microbiol., 72, 4338-4346 (2006).

Di Cesare, A., G. M. Luna, C. Vignaroli, S. Pasquaroli, S. Tota, P. Paroncini and F. Biavasco: Aquaculture can promote the presence and spread of antibiotic-resistant Enterococci in marine sediments. PLoS ONE 8:e6283810.1371/journal. Pone, 0062838 (2013).

Fauquet, C. M., M. A. Mayo, J. Maniloff, U. Desselberger and L. A. Ball: Virus Taxonomy. VIIIth report of the International Committee on Taxonomy of Viruses. Academic Press (2005).

Goszczynska, T., J. Serfontein and S. Serfontein: Introduction to practical Phytobacteriology. Bacterial Disease Unit. ARC-Plant Protection Research Institute Pretoria, South Africa (2000).

Gupta, R. and Y. Prasad: Efficacy of polyvalent bacteriophage P-27/HP to control multidrug resistant Staphylococcus aureus associated with human infection. Curr. Microbiol., 62, 255-260 (2011).

Hollis, A. and Z. Ahmed: Preserving antibiotics, rationally. New Engl. J. Med., 369, 2474-2476 (2013).

Imbeault, S., S. Parent, M. Lagace, C. F. Uhland and J. F. Blais: Using bacteriophages to prevent furunculosis caused by Aeromonas salmonicida in farmed brook trout. J. Aquat. Anim. Heth.,18, 203 214 (2006).

Kwan, T., J. Liu, M. DuBow, P. Gros and J. Pelleteir: Comparative genomic analysis of 18 Pseudomonas aeruginosa bacteriophage. J. Bacteriol., 188, 1184 - 1187 (2006).

Khairnar, K., M. P. Raut, R. H. Chandekar, S. G. Sanmukh and W. N. Paunikar: Novel bacteriophage therapy for controlling metallobeta-lactamase producing Pseudomonas aeruginosa infection in catfish. BMC Vet. Res., 9, 264 (2013).

Kumari, S., K. Harjai and S. Chhibber: Characterization of P. Aeruginosa $\mathrm{PAO}$ specific bacteriophage isolated from sewage samples. Am. J. Biomed. Sci., 1, 91-102 (2009). 
Kutter, E. and A. Sulakvelidze: Bacteriophages: Biology and Applications. CRC Press (2004).

Laemmli, U. K.: Cleavage of structural proteins during the assembly of the head of bacteriophage T4. Nature, 227, 680-685 (1970).

Laanto, E., R. K. Penttinen, J. K. H. Bamford and L. R. Sundberg: Comparing the different morphotypes of a fish pathogen implications for key virulence factors in Flavobacterium columnare. BMC Microbiol., 14, 170 (2014).

Laanto, E., J. K. H. Bamford, J. J. Ravantti and L. - R. Sundberg: The use of Phage FCL-2 as an alternative to chemotherapy against columnaris disease in aquaculture. Front. Microbiol., 6, 829. (2015).

Maniloff, J. and H. W. Ackermann: Taxonomy of bacterial viruses, establishment of tailed virus genera and the order Caudovirales. Achi.Virol.,143, 2051-2063 (1998).

Muziasari, W. I., K. Pamanen, T. A. Johnson, C. Lyra, A. Karkman, R. D. Stedtfeld, M. Tamminen, J. M. Tiedje and M. Virta: Aquaculture changes the profile of antibiotic resistance and mobile genetic element associated genes in Baltic Sea sediments. FEMS Mirobiol. Ecol., 92, 1-7 (2016).

Prasad, Y. and T. A. Qureshi: Histo-pathological investigations on bacterial heamorrhagic septicaemia in Cyprinus carpio communis (Linn.). Zeil. Angrew. Zoologie.,80, 313-324 (1994).

Prasad, Y. and T. A. Qureshi: Histo-pathological and haematological investigations on Clarias batrachus(Linn.) affected with ulcer diesase. Pakistan. J. Zool., 27, 273-276 (1995).

Prasad, Y.: Isolation, characterization and efficacy of bacteriophages against pathogenic Pseudomonas and Flavobacterium associated with bacterial fish diseases, for therapeutic uses in aquaculture. Approved Final Technical Progress Report, DBT Project (2005-2008), pp.42 (2008).

Prasad, Y., Arpana and D. Kumar: Isolation and efficacy evaluation of virulent bacteriophage specific to fish pathogenic bacterium, $F$. columnare. J. Appl.Ani. Res., 38, 169-174 (2010).

Prasad, Y., D. Kumar, A. K. Sharma, D. Nisha and A. S. Ninawe: Isolation and efficacy characterizations of lytic bacteriophages against antibiotic resistant Pseudomonas fluorescens from Sub Himalayan region. Biochem. Cell. Arch.,10, 21-29 (2010).

Prasad, Y., Arpana, D. Kumar and A. K. Sharma : Lytic bacteriophages specific to Flavobacterium columnare rescue catfish, Clarias batrachus (Linn.) from columnaris disease. J. Environ. Biol., 32, 161-168 (2011).

Parvez, N. and M. S. A. Mudarris: Investigation on the bacterial haemorrhagic septicemia disease of Cyprinus carpio and Channa striatus. Poult. Fish Wildl. Sci., 2, 116 (2014)

Qureshi, T. A., Y. Prasad, S. A. Mastan and R. Chauhan: Involvement of fungal and bacterial pathogens in EUS of fish. $\ln :$ Aquaculture feed and health (Ed.: J. John and A.S. Ninawe). Biotech Consortium India Ltd., New Delhi, pp.126-139 (2000).

Radhakrishnan, A. and M. A. Subramanian: Characterization and lytic activity of Pseudomonas fluorescens phage from sewage. Braz. J. Microbiol., 43, 356 - 362 (2012).

Sambrook, J. and D. W. Russell: Molecular cloning, a Laboratory Manual $3^{\text {rd }}$ Edn., Cold Spring Harbar Laboratory Press, N.V., pp 2.1-2.110 (2001).

Sillankorva, S., P. Neubauer and J. Azeredo: Isolation and characterization of a T7 - like lytic phage for Pseudomonas fluorescens. BMC Biotechnol., 8, 80 (2008).

Stenholm, A. R., I. Dalsgaard and M. Middelboe: Isolation and characterization of bacteriophage infecting the fish pathogen Flavobacterium psychrophilum. Appl. Environ. Microbiol., 74, 4070-4078 (2008).

Taddei, F. and M. De Paepe: Viruses' life history: Towards a mechanistic basis of a trade-off between survival and reproduction among phages. PLoS Biol., 4, e193 (2006). 